\title{
A digitális átállás könyvtári aspektusai a nemzetközi trendek tükrében*
}

\begin{abstract}
„A kiberfizikai megközelítések »okos«-városokhoz, gyártási, közlekedési, logisztikai, energetikai rendszerekhez vezethetnek, és hozzájárulhatnak egy újabb életminőség megteremtéséhez. Ez utóbbi vonatkozásban már kiberfizikai társadalomról (Cyber-Physical Society) is beszélhetünk, ami már nemcsak a fizikai és kibernetikai tereket, hanem az emberi, társadalmi, kulturális szférákat is magában foglalja."

A 4. ipari forradalom elkerülhetetlenül megváltoztatja világunk müködését. Az exponenciális ütemben zajló fejlödés hatására átalakulnak a munkakörülmények, továbbá megváltoznak a társadalom mindennapjait befolyásoló tényezők: okosvárosok jönnek létre, átalakul a fogyasztói társadalom müködése és tovább erősödik az információ értéke. A társadalomnak szüksége van egy olyan intézményrendszerre, amely segíti alkalmazkodását a gyorsan fejlődő világhoz. A könyvtárak jövőjét határozza meg, milyen mértékben tudják ezt a szerepkört felvállalni.

Az 1780-ban kezdődő, 70 évig tartó első ipari forradalom a gőz erejét használó gépekkel alakította át a társadalom mủködését. A lezárását követően 20 év múlva induló második ipari forradalom a villamosság és a tömeggyártás újdonságát jelentette 1914-ig. A harmadik ipari forradalom kezdetét 1918-ra teszik, amely az elektromosság, automatizálás, valamint a számítógépek elterjedését foglalja magába. ${ }^{2}$ A jelenleg tartó negyedik ipari forradalom a harmadik ipari forradalomra épül, legfőbb jellemzője a technológiák fúziója, ami a fizikai, a digitális és a biológiai szférák közötti vonalak elmosódását idézi elö. Kiberfizikai rendszerek jönnek létre, ahol a hardver és a szoftver közötti határ elmosódik, a rendszerek kihasználják a hálózat és a mesterséges intelligencia lehetőségeit, és a gépek már nemcsak az emberekkel, hanem egymással is kommunikálnak. A korábbi ipari forradalmaktól eltérően a negyedik ipari forradalom sajátossága, hogy egyszerre minden országban, minden iparágra hatással van. ${ }^{3}$
\end{abstract}

*A tanulmány A digitális átállás könyvtári aspektusai. = Tudományos és Müszaki Tájékoztatás, 66. évf. 2019. 11. sz. cikk bővített kiadása, és a Bolyai János Kutatási Ösztöndíj támogatásával készült.

${ }^{1}$ Monostori László: A számítógépes szerszámgépvezérlésektől a kiberfizikai termelési rendszerekig. 2015. https://mta.hu/vi-osztaly/a-szamitogepes-szerszamgepvezerlesektol-a-kiberfizikai-termelesi-rendszerekig-monostori-laszlo-rendes-tag-szekfoglalo-eloadasa-107244 (2019. október 10.)

${ }^{2}$ Schwab, Klaus: The Fourth Industrial Revolution What It Means and How to Respond. 2015. Foreign Affairs https://www.foreignaffairs.com/articles/2015-12-12/fourth-industrial-revolution (2020. május 11.)

${ }^{3}$ Uo. 


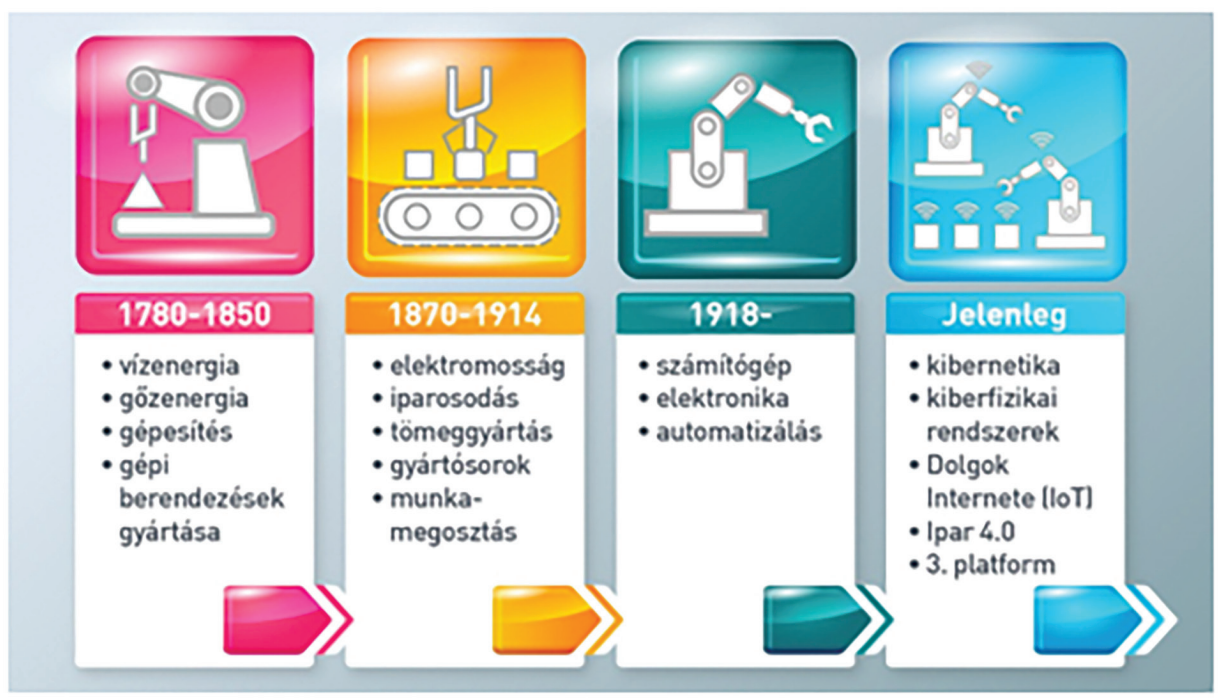

1. ábra. Az ipari forradalmak

Ennek következménye, hogy rövid időn belül a legtöbb munkahelyen teljesen új technikai eszközök jelennek meg, átalakítva a hagyományos munkavégzést. A megváltozott munkakörnyezetben a dolgozóktól elvárt képességek is átalakulnak (1. táblázat).

\section{Az elvárt készségek sorrendje}

\section{5}

1. komplex problémamegoldás

2. $\quad$ együttmüködési készség

3. emberek irányítása

4. kritikai gondolkodás

5. tárgyalási készség

6. minőség-ellenőrzés

7. szolgáltatás attitüd

8. döntéshozatali készség

9. aktív figyelem

10. kreativitás

\section{0}

komplex problémamegoldás

kritikai gondolkodás

kreativitás

emberek irányítása

együttműködési készség

érzelmi intelligencia

döntéshozatali készség

szolgáltatói attitüd

tárgyalási készség

kognitív rugalmasság

1. táblázat. A dolgozóktól elvárt képességek

Míg 2015-ben a kritikai gondolkodás nem szerepelt a legfontosabb három elvárt képesség között, és a kreativitás is csak a tizedik legfontosabb kompetencia volt, addig 2020-ra a komplex problémamegoldás képessége után ezek vezetik a listát, jelentős átalakulást okozva a munkaadók által elvárt képességek preferenciájában. 


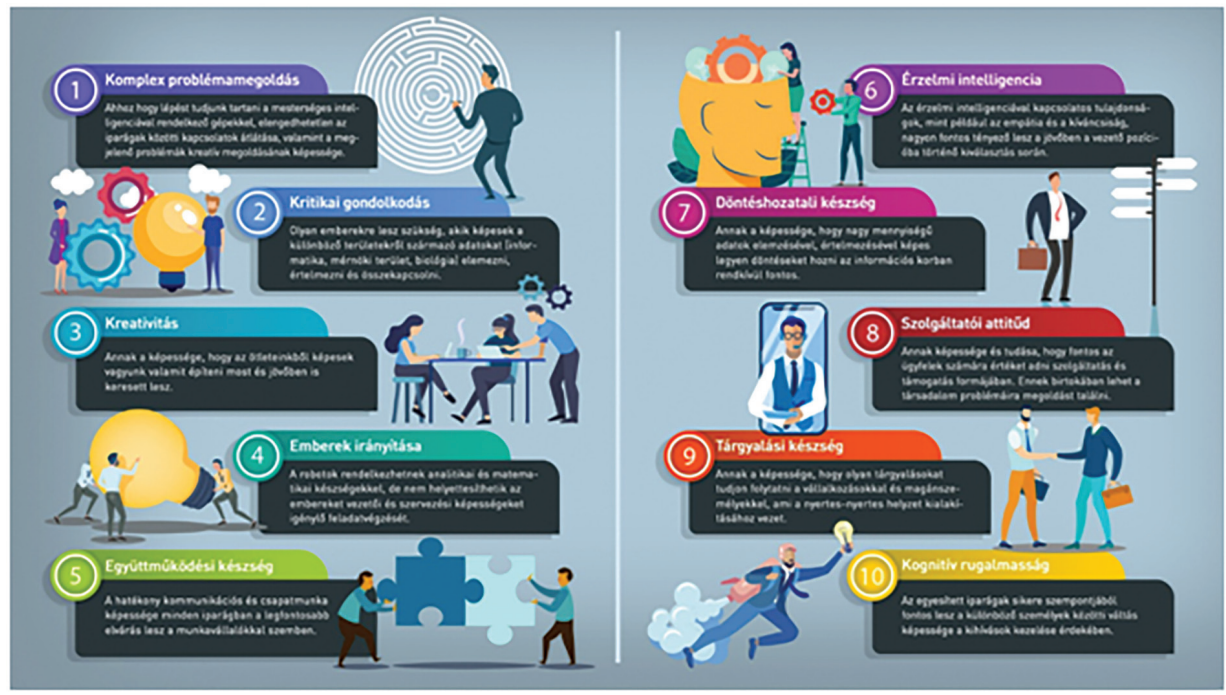

2. ábra. 2020-ban elvárt képességek a Word Economy Forum ajánlása alapján ${ }^{4}$

A drasztikus változások nem csak az elvárt képességekben érhetők tetten: az adatelemzések szerint jelentős számú szakma tünik el és újak jelennek meg. Egyrészt ez természetes folyamat, hiszen korábban nem volt szükség szélturbina-mérnökökre, okosváros-menedzserekre stb., azonban a változás gyorsasága miatt nehéz a társadalmi adaptáció, és számtalan kérdés vetődik fel:

- Vajon képes-e az oktatási rendszerünk átalakulni, és az elvárt képességekkel felruházni a tanulókat?

- Mindezt olyan sebességgel, ahogy a világban zajló változások megkövetelik?

- Ki fog segíteni az oktatási rendszeren kívüli személyeknek felkészülni a megváltozott munkaerő-piaci elvárásokra?

\section{A könyvtár mint digitális oktatási központ}

Az amerikai lakosság a 4. ipari forradalom hatására bekövetkező új technológiai eszközök használatára való felkészitést, valamint a digitális kompetenciaszint-fejlesztést a könyvtáraktól várja: A Pew Research Center évente vizsgálja a könyvtárak megítélését az amerikai lakosság körében. 2016-ban 1601 lakost kerestek meg telefonon, és a válaszadók 77\%-a ragaszkodott a könyvtárhoz (a 2015-ös felmérés során az ,amerikaiak 53\%-a valamilyen interakciót folytatott egy közkönyvtárral - akár személyes látogatásként, egy könyvtár honlapján,

${ }^{4}$ Desjardins, Jeff: 10 skills you'll need to survive the rise of automation. 2018. https://www. weforum.org/agenda/2018/07/the-skills-needed-to-survive-the-robot-invasion-of-the-workplace (2019. július 30.) 
vagy egy mobilalkalmazáson keresztül"). ${ }^{5}$ A 2016-os felmérésben - melyben a lakosokat arról kérdezték, hogy milyen szolgáltatásokat várnak el a könyvtáraktól - az alábbi válaszokat olvashatjuk (3. ábra):

- „Olyan programokat kínáljon, amelyek megtanítják az embereket (beleértve a gyerekeket és az idősebb polgárokat is) használni a digitális eszközöket, például számítógépeket, okostelefonokat és alkalmazásokat.

- Több kényelmes teret biztosítson a munkához és a pihenéshez.

- Vásároljon 3D nyomtatókat és egyéb digitális eszközöket, hogy az emberek megtanulják, hogyan használják őket különböző objektumok készítésére.

- Csökkentse a nyomtatott könyveket a nyilvános helyeken, hogy több helyet biztosítson a technológiai központoknak, olvasótermeknek, tárgyalóknak és kulturális esteknek."

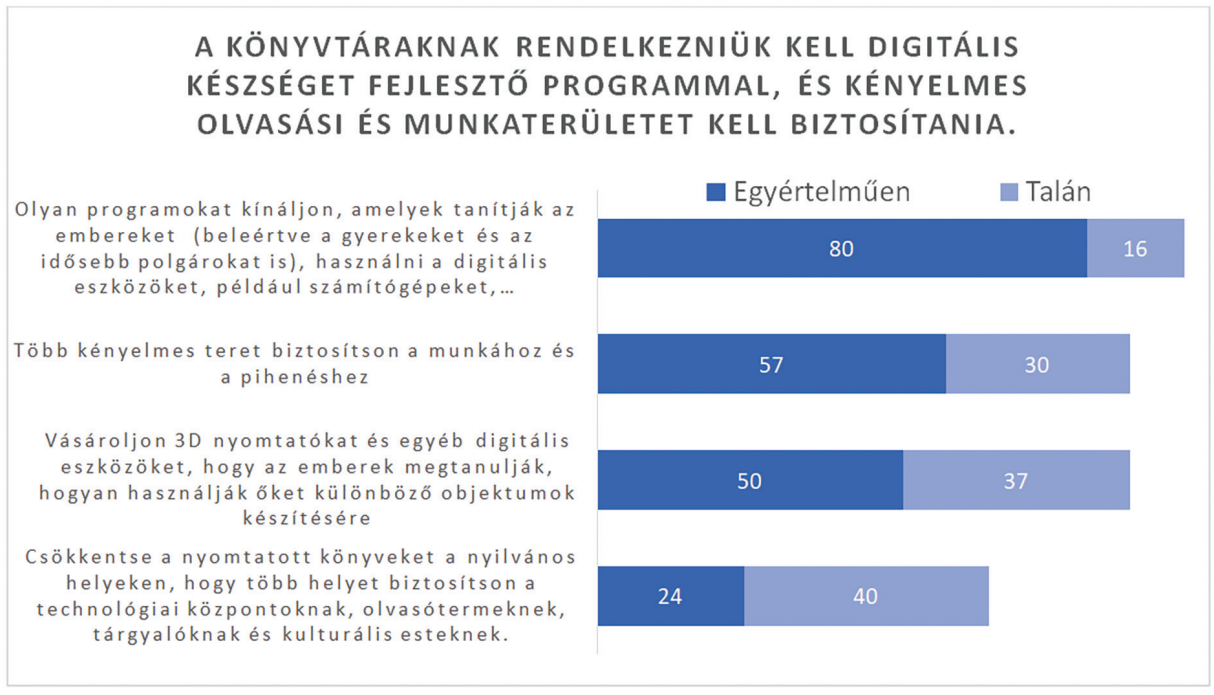

3. ábra. Pew Research Center felmérése 2016. Amerika ${ }^{7}$

A digitális technológiához való hozzáférés biztosítása nemzetközi szinten is megjelenik könyvtári feladatként:

- Az IFLA már 2013-ban a legfontosabb 5 trend között tüntette fel, hogy „az új technológiák átalakítják a globális információs gazdaságot” és erre a könyvtáraknak reagálniuk kell.

${ }^{5}$ Horrigan, John B.: Libraries. 2016. https://www.pewinternet.org/2016/09/09/libraries-2016 (2019. július 30.)

${ }^{6}$ Uo.

${ }^{7}$ Uo., ford. a szerző. 
- A 2016-ban kiadott stratégiai elveik között még aktuálisabban foglalkozik a problémakörrel. ${ }^{8}$

Bár a jelentésben a technológiai eszközök közül a 3D nyomtatás könyvtári alkalmazása és a mobiltechnológia-adta előnyök kiaknázása jelenik meg hangsúlyosan, a lehetőségek köre ennél jóval bővebb. Ezért érdemes a könyvtáraknak a társadalmi igényeket mérniük, és a saját környezetükhöz igazítaniuk a technológiai fejlesztéseiket.

\section{A könyvtár mint tanulási környezet}

Az országok jövőjét alapvetően fogja meghatározni, hogy milyen gyorsan tudnak reagálni a technológiai fejlődésre, és milyen gyorsan tud az oktatási rendszerük adaptálódni a megváltozott elvárásokhoz. Az oktatási rendszernek:

- a jelenlegi zárt, kész tudásrendszer átadása helyett a képességek kialakítására kell helyeznie a hangsúlyt;

- figyelembe kell vennie, hogy az iskolarendszerbe kerülő tanulók már nem az ipari társadalmak iskoláinak gyermekei, hanem az információs társadalomba születtek;

- olyan képzéseket és képzettséget kell nyújtania a közép- és felsőoktatásban, amely piacképes a negyedik ipari forradalom hatására átalakuló gazdaságban.

A három elvárás támogatására képességmodelleket hoztak létre. A 2010-es évek első felétől számos napvilágot látott, közülük a legelfogadottabb a World Economic Forum 2015-ben kiadott változata, melyet Racsko Réka ${ }^{9}$ jelentetett meg magyarul (4. ábra):

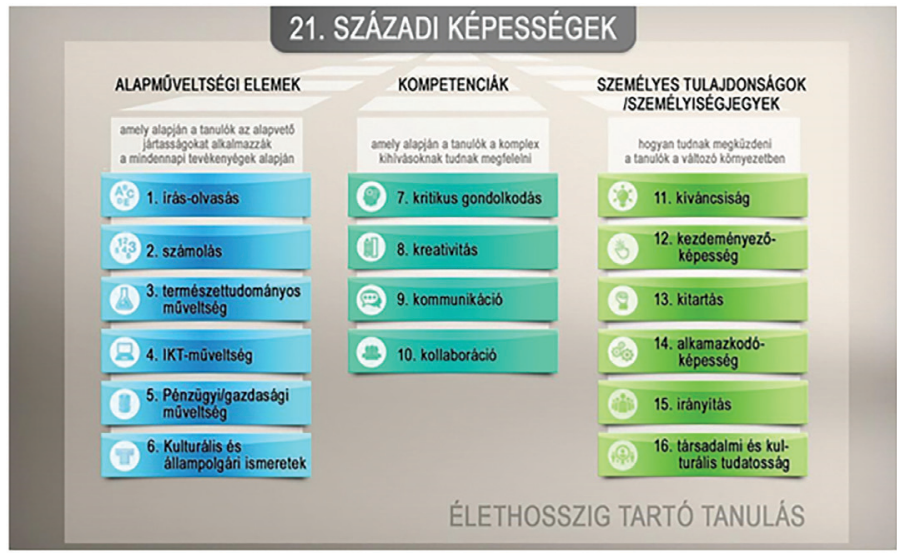

4. ábra. 21. századi képességek

${ }^{8}$ IFLA Report Update. 2016. https://trends.ifla.org/files/trends/assets/trend-report-2016-update. pdf (2019. szeptember 30.)

${ }^{9}$ Racsko Réka: Digitális átállás az oktatásban. Budapest, Gondolat. 2017. https://doi.org/ 10.17717/IQKONYV.Racsko.2017 
Látható, hogy az írás-olvasás alapműveltségi területek mellett az IKT-müveltség (valamint a könyvtárak jövője szempontjából nem elhanyagolható: kulturális és állampolgári ismeretek) is megjelenik alapmüveltségi elemként. Az IKT-müveltség, vagy a szakirodalomban több helyen ,digitális írástudásként” megnevezett alapmüveltségi elem fejlesztésében a könyvtáraknak aktív szerepet kell vállalniuk!

Ez az elvárás összhangban van az Európai Unió 2020-ig tartó digitális menetrendjével, amelynek része a digitális írástudás fejlesztése. Az Európai Unió a nemzeti kormányok feladataként jelölte meg, hogy a társadalmi és gazdasági fejlesztés érdekében javítsanak a helyzeten. Ennek hatására a magyar kormány a 2014-2020-ig tartó infokommunikációs stratégiájában tüzte ki célul, hogy 2020ra a teljes lakosság digitális írástudását $40 \%$ alá csökkentse. Ennek eléréséhez a kulturális és közösségi intézmények aktív részévételére számít. ${ }^{10} 2020$-hoz közeledve jól látható, hogy a célértéket nem fogja elérni az ország. A 2018-as PISA-mérés eredményeit az OECD csak 2019 decemberében fogja nyilvánosságra hozni, de a 2012-es és 2015-ös PISA-mérések lesújtó képet mutatnak a magyar tanulók digitáliskompetencia-szintjéről. A legfrissebb mérések sem biztatóak! A Microsoft Magyarország 25 innovatív iskolában vizsgálta a 13-18 éves tanulók digitális kompetenciáit a DigCompEdu 2.0 keretrendszerére alapozva, és megállapították, hogy ,a diákoknak föként az okoz fejtörést, ha a világhálón kell válaszok után kutatniuk, majd mérlegelni és értékelni a találtakat. A célzott internetes keresés, az adatfeldolgozás és az álhírek felismerésének képessége a tesztet kitöltő intézmények mindegyikében fejlesztésre szorul. A többi négy dimenzióban (problémamegoldás, biztonság, tartalomelőállítás, kommunikáció) átlagosan jobb, 50\% feletti eredmények születtek, de nagyobb szórással." ${ }^{11}$ Tehát ezeken a területeken vannak tehetséges és lemaradt tanulók, míg az információszerzés és -értelmezés területén egységesen rossz a helyzet. Az adatok értelmezésénél szeretném kiemelni, hogy a mérések innovatív iskolákban történtek, és itt is szomorú helyzetképet láthatunk.

A fenti hiányosságok elkerülésére hívja fel a figyelmet a bemutatott képességmodell is. Láthatjuk, hogy nemcsak az alapmüveltségi elemek kialakítása az iskola feladata, hanem a kompetenciák fejlesztése is (továbbá hangsúlyosan jelennek meg a személyes tulajdonságok fejlesztési feladatai is). A kompetenciák fejlesztése több szempontból is kulcsfontosságú a tanulók jövőjét tekintve.

Gerd Leonard jövőkutató szerint ,a digitális transzformációnak nevezett ipari forradalom a felgyorsult fejlődésnek köszönhetően a következő 20 évben

\footnotetext{
${ }^{10}$ Lengyelné Molnár Tünde: Digitális írástudás fejlesztése a könyvtárakban. = Tudományos és Müszaki Tájékoztatás, 63. évf. 2016. 2. sz. 65-72. p.

${ }^{11}$ Microsoft, News Center: Van mit fejleszteni a Z-generáció digitális kompetenciáin. 2018. https://news.microsoft.com/hu-hu/2018/07/02/van-mit-fejleszteni-a-z-generacio-digitaliskompetenciain (2019. november 29.)
} 
több változást hozhat, mint amennyit az egész emberi társadalom eddig átélt. A kérdés az, hogy az egyének vagy éppen az országok hogyan reagálnak a szoftverek és gépek evolúciójára, a valós idejü információk és a bárhol elérhető adatok jelenségére és az ezáltal létrejövő új kihívásokra." 12 Ez az oktatásra nézve azt jelenti, hogy az a tanuló, aki napjainkban kezdi el az első osztályt, a képzési rendszerből kikerülve már egy új világban találja magát. A boldogulásának kulcseleme, hogy az oktatási rendszer felkészítette-e a megváltozott munkakörülményekhez szükséges adaptáció kompetenciáival. Rendelkezik-e azzal a kreativitással, amire szüksége lesz a robotizálódó világunkban? Képes-e munkája során folyamatosan keresni azokat a lehetőségeket, amelyekkel növeli a hatékonyságot? Figyeljük meg, a képességprofilban a kollaboráció képessége is megjelenik! Míg ,a kooperáció során elosztják egymás között a feladatokat, és minden csoporttag egy bizonyos részfeladat elvégzéséért a felelös, addig a kollaboráció során a munkamegosztás spontán jön létre, attól függően, hogy ki mivel tud hozzájárulni a közös munkához." ${ }^{13}$ A kommunikáció képességét nem kell magyarázni, de az ábrán a kompetenciák első helyén látható kritikus gondolkodás helyett helyesebb a kritikai gondolkodás kifejezés használata. A kritikai gondolkodás egy olyan terület, ahol a könyvtárak hatékonyan segíthetik oktatási intézmények munkáját. A kritikai gondokoldás Dewey szerint „az a képesség, amellyel felkutathatjuk meggyőződéseink, hiedelmeink alapját és az őket fenntartó információkat, ez egy Én-re irányuló reflektív gondolkodás." ${ }^{14}$

\section{Hol fejleszthető a tanulók digitális kompetenciája és kritikai gondolkodása?} A 2015-ös PISA-mérések részletes elemzése során kimutatták, hogy összefüggés van a tanulók digitális kompetencia szintje, valamint ,a közvetlen oktatói-nevelöi környezet között, legyen szó elsődleges vagy másodlagos szocializációs színtérről, melyben a tanuló jelen van."15

\section{A tanulási környezet kulcsfontosságú!}

Racsko Réka ${ }^{16}$ az észt és a finn nemzeti alaptanterv tartalomelemzése során kimutatta, hogy mindkét országban a tanulási környezet egyik legfontosabb eleme a könyvtár. Az észteknél az iskolai könyvtár fontos része a tanulási környezetnek,

${ }^{12}$ Racsko Réka: i.m. https://doi.org/10.17717/IQKONYV.Racsko.2017

${ }^{13}$ Benedek András - Horváth Cz. János - Molnár György - Nagy Gábor Zsolt - Nyíri Kristóf Szabó Erzsébet Mária - Tóth Péter - Verebics János: Digitális pedagógia 2.0. Budapest, Typotex Kiadó. 2012.

${ }^{14}$ Jákó Katalin: A kritikai gondolkodás. = A kritikai gondolkodás fejlesztése. Módszertani segédlet. Szerk. Kovács Zoltán. Kolozsvár, Kolozsvári Egyetemi Kiadó. 2009. 9-41. p.

${ }^{15}$ Tóth-Mózer Szilvia - Kárpáti Andrea: A digitális kompetencia kognitív dimenziója és öszszefüggésrendszere egy empirikus kutatás tükrében. = Magyar Pedagógia, 116. évf. 2016. 2. sz. 121-150. p. https://doi.org/10.17670/mped.2016.2.121 (2019. november 27.)

${ }^{16}$ Racsko Réka: i.m. https://doi.org/10.17717/IQKONYV.Racsko.2017 
míg a finneknél a tantermen kívüli lehetőségek alkalmazása a leghangsúlyosabb eleme a tanulási környezetnek, melyen belül a könyvtár szerepel az első helyen (de már nem korlátozva az iskolai könyvtárakra a fogalmát). Szomorú módon a magyar nemzeti tantervben eddig sem volt megtalálható ez a kapcsolat, az új NAT-ban pedig tovább csökkent a könyvtárak szerepe. Eközben pedig nemzetközi szinten a könyvtári stratégiák kulcsterülete a digitáliskompetencia-fejlesztés, az IFLA mindegyik évi jelentésében megtalálható. Ha megnézzük az IFLA kontinensenkénti elemzéseit, mindenhol megjelenik a digitáliskompetenciafejlesztés a könyvtár feladataként.

E téren a magyarországi könyvtárak is elkötelezettek. Az elmúlt 5-8 év könyvtári fejlesztési pályázataiban tapasztalható irányok között a tanulók számára digitáliskompetencia-fejlesztést szolgáló játékos módszertan, valamint az ehhez kapcsolódó tanulási környezet kialakítása hangsúlyosan megtalálható. Folynak kutatások az adaptív tanulási környezetek könyvtári környezetben történő biztosítására. ${ }^{17}$ Abban viszont tovább kellene lépni, hogy az oktatási intézmények is ismerjék és használják ki a könyvtárakban lévő lehetőségeket. A kapcsolatépítésnek több szinten kell megvalósulnia:

- Helyi szinten el kell érni, hogy tovább javuljon az iskolák és a könyvtárak közötti kapcsolat.

- Országosan meg kell jelennie a könyvtáraknak a pedagógiai konferenciákon, módszertani fejlesztéseket célzó eseményeken.

- Döntéshozói szinten az érdekérvényesítő szervezeteknek el kell érniük, hogy a nemzeti alaptantervben hangsúlyt kapjon a könyvtár mint tanulási környezet.

Nemzetközi szinten jól láthatók e törekvések. Az IFLA minden évben összefoglalja a világ könyvtárainak trendjeit, a müködést befolyásoló tényezőket. „A 14 nyelvre lefordított, a világ 30 országában, több mint 60 szakmai rendezvény keretében megvitatott trendjelentés és a kapcsolódó bibliográfia aktualizálására 2016-ban került sor." ${ }^{18}$ Kvalitatív tartalomelemzéssel vizsgálva a 2016os stratégiai kiadványt, a könyvtárak jövőképében látható a leghangsúlyosabb jogi védelmi kérdéseken túl a technológiai fejlödés hatása, valamint a tanulási folyamatok támogatása.

${ }^{17}$ Czeglédi László: Adaptív tanulási környezetek könyvtári támogatása. Eger, Agria Média. 2017. https://doi.org/10.17048/AM.2018.11

${ }^{18}$ Kiszl Péter: Ki viszi át...? A könyvtárak társadalmi felelősségvállalása a digitális korban. = Tudományos és Müszaki Tájékoztatás, 64. évf. 2017. 1. sz. 1-23. p. 


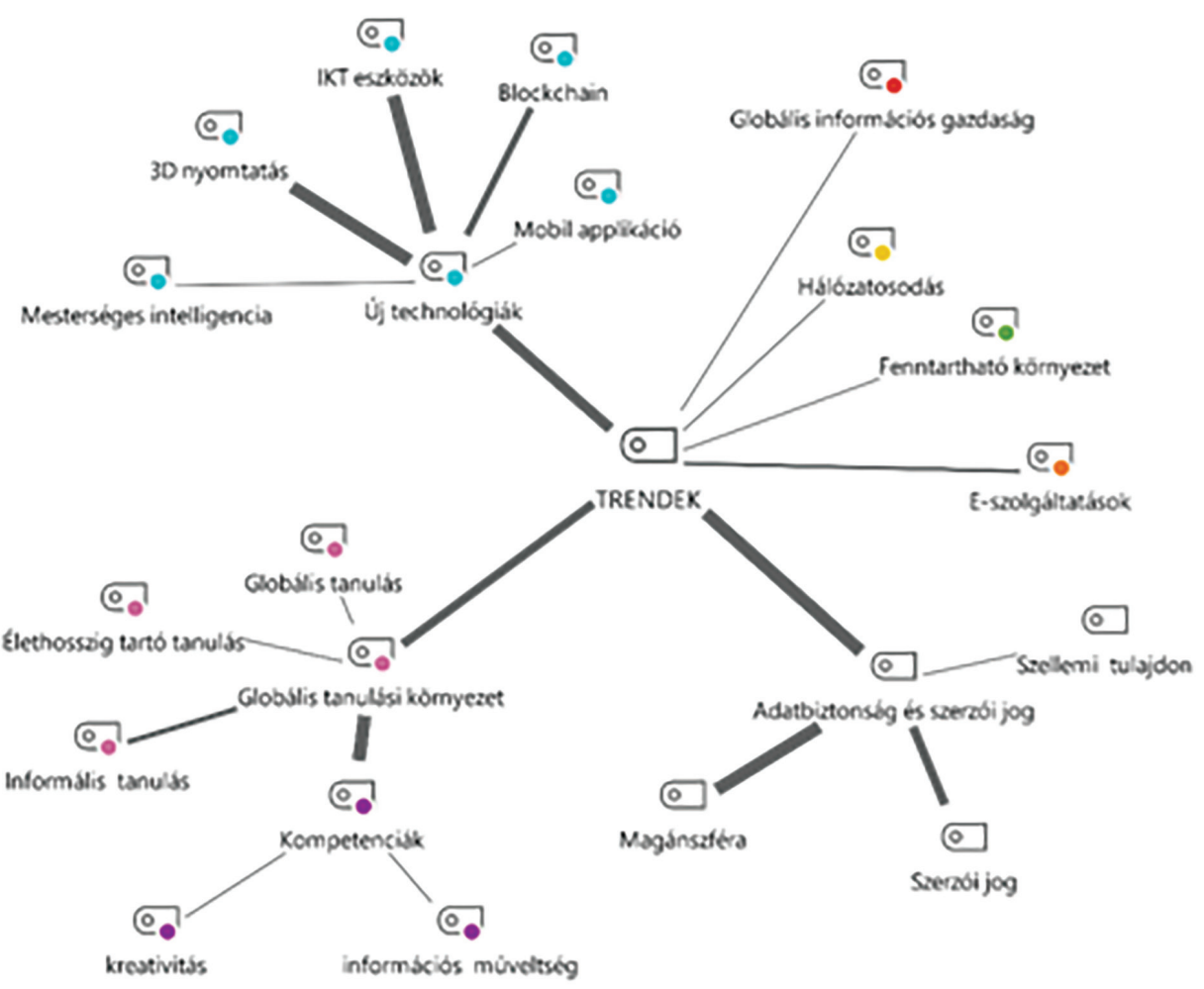

5. ábra. IFLA Trend Report 2016 Update kódtérképe

A MaxQDA számítógépes tartalomelemző szoftverrel készített kódtérképén a vonalvastagságok jelzik a kapcsolat erősségét. Ez jól tükrözi, hogy:

- a jogvédelemben a szerzői jog mellett hangsúlyos a magánszféra jogbiztonságának támogatása;

- a technológiai fejlődés eredményei közül a 3D nyomtatás és egyéb IKTeszközök könyvtári alkalmazását tüzi ki célul a stratégia, de az IFLA felhívja a figyelmet arra is, hogy a „blockchain forradalom paradigmaváltást eredményezett globális társadalmunkban és gazdaságunkban," 19 a tartalomelemzés ábráján pedig látható, hogy ez nagyon hangsúlyosan jelenik meg a dokumentumban;

- az oktatás jövőképében fontos szerepet szánnak a könyvtáraknak. Ki kell venniük a részüket az online oktatásból, valamint segíteniük kell a társadalmat a kompetenciafejlesztésben is.

${ }^{19}$ Trending: IFLA Releases Trend Report Update 2016. https://trends.ifla.org/files/trends/ assets/trend-report-2016-update.pdf (2019. november 20.) 


\section{A könyvtár mint online oktatási színtér}

A megváltozott gazdasági, társadalmi, környezeti tényezők, korunk impulzusokban bővelkedő világa érzékelhető változásokat idézett elő az iskolákban is. Úgy tünik, a tanulás hagyományos szervezése sok esetben nem képes megvalósítani a diákok bevonódását a tanulási folyamatba. ${ }^{20} \mathrm{~A} 21$. századi oktatás középpontjában az egyénnek kell állnia, a hangsúly a tanult ismeretek alkalmazásának képességére helyeződik át, annak mennyisége helyett. A pedagógus fontos feladata, hogy olyan tanulási környezeteket hozzon létre, melyek támogatják és elősegítik az ismeretek alkalmazásának képességeit. ${ }^{21} \mathrm{Az}$ élethosszig tartó tanulás elengedhetetlen feltétele lesz a jövő munkavállalójánál, hiszen a gyorsan változó szakmákra, képességekre reagálni csak folyamatos önképzéssel, fejlődéssel lehet. Az élethosszig tartó tanulás nem csak az állam és a nemzetközi szervezetek nyilatkozataiban jelenik meg, kimutatható módon annak igénye a gyakorlatban is beépül az emberek gondolkodásmódjába, a munkáltatók elvárásai közé. Megjelenik a tapasztalatok, a nem formális keretek közt szerzett tudás elismerésének az igénye, ami az USA-ban már bevett szokás, ${ }^{22}$ de lassan a magyarországi felsőoktatási intézményekben is kezd kialakulni a tapasztalatok beszámítására, kreditre váltására vonatkozó validálási folyamat. Üdvözölhető módon ezzel ellentétes irányokat is tapasztalhatunk: növekszik azoknak a száma, akik csak kíváncsiságuk kielégítésére, egy-egy folyamat mélyebb megismerésére iratkoznak be a felsőoktatási intézmények tantárgyaira, és nem akarnak diplomát szerezni, csak (kredit)igazolást az adott tárgy elvégzéséről. A jövőben ennek a tevékenységnek hatására az online oktatási formák további erősödése, valamint az online oktatást nyújtó intézmények számának növekedése prognosztizálható.

Magyarországon a könyvtárak, múzeumok most kezdenek csatlakozni az online képzéseket nyújtó intézmények sorához. Ennek jelentőségét az Európai Bizottság Horizont-jelentése támasztja alá, ahol az Európai Unió iskoláiban bekövetkező trendeket mutatják be 2020-ig (2014-ben kiadva). Az online oktatás jövőjéről szóló jelentés alapján 2018-2020 között az online tanulás a közoktatásban is megjelenik, miközben Magyarországon még a felsőoktatásban sem terjedt el (2. táblázat).

\footnotetext{
${ }^{20}$ Virág Irén: Tanuláselméletek és tanítási-tanulási stratégiák. Eger, Líceum Kiadó. 2014.

${ }^{21}$ Komló Csaba - Lengyelné Molnár Tünde - Virág Irén: LEGO WeDo-ra alapozott, projektszemléletű ismeretátadás az alsó tagozatban. Eger, Eszterházy Károly Egyetem. 2019.

${ }^{22}$ Derényi András: Tanulás a felsőoktatásban. = Education, 2008. 2. sz. 9. p. http://www.eduonline.eu/hu/letoltes.php?fid=tartalomsor/716 (2019. november 20.)
} 


\begin{tabular}{|c|c|c|}
\hline $\begin{array}{l}\text { Jelen van } \\
\text { (gyors trendek, } \\
1-2 \text { év) }\end{array}$ & $\begin{array}{c}\text { Kopogtat } \\
\text { (középtávú trendek, } \\
3-5 \text { év) }\end{array}$ & $\begin{array}{l}\text { Idő kell hozzá } \\
\text { (hosszú távú trendek, } \\
\text { legalább } 5 \text { év) }\end{array}$ \\
\hline $\begin{array}{l}\text { A nyitott források } \\
\text { (tananyagok) } \\
\text { felértékelődése }\end{array}$ & $\begin{array}{c}\text { A közösségi média } \\
\text { szerepének növekedése }\end{array}$ & A tanári szerep átértékelődése \\
\hline $\begin{array}{l}\text { A kevert (blended) } \\
\text { tanulás integrálása }\end{array}$ & $\begin{array}{l}\text { Az online tanulás } \\
\text { elterjedése }\end{array}$ & $\begin{array}{l}\text { Az adatokra alapozott tanulás } \\
\text { és értékelés elterjedése }\end{array}$ \\
\hline
\end{tabular}

2. táblázat. Az oktatástechnológia adaptációját felgyorsító trendek ${ }^{23}$

A trendeket vizsgálva - ami napjainkban már az Európai Unió közoktatási intézményeiben nem jövőkép, hanem alkalmazott módszertan - látható, hogy az Európai Unió a hagyományos oktatási módszerektől távolodó, az élethosszig tartó tanulásra jobban felkészító oktatási rendszert javasol.

Az oktatási formák is az elvárásoknak megfelelöen alakulnak. A 6. ábrán látható fejlődési szakaszok az online oktatás átalakulását szemléltetik:

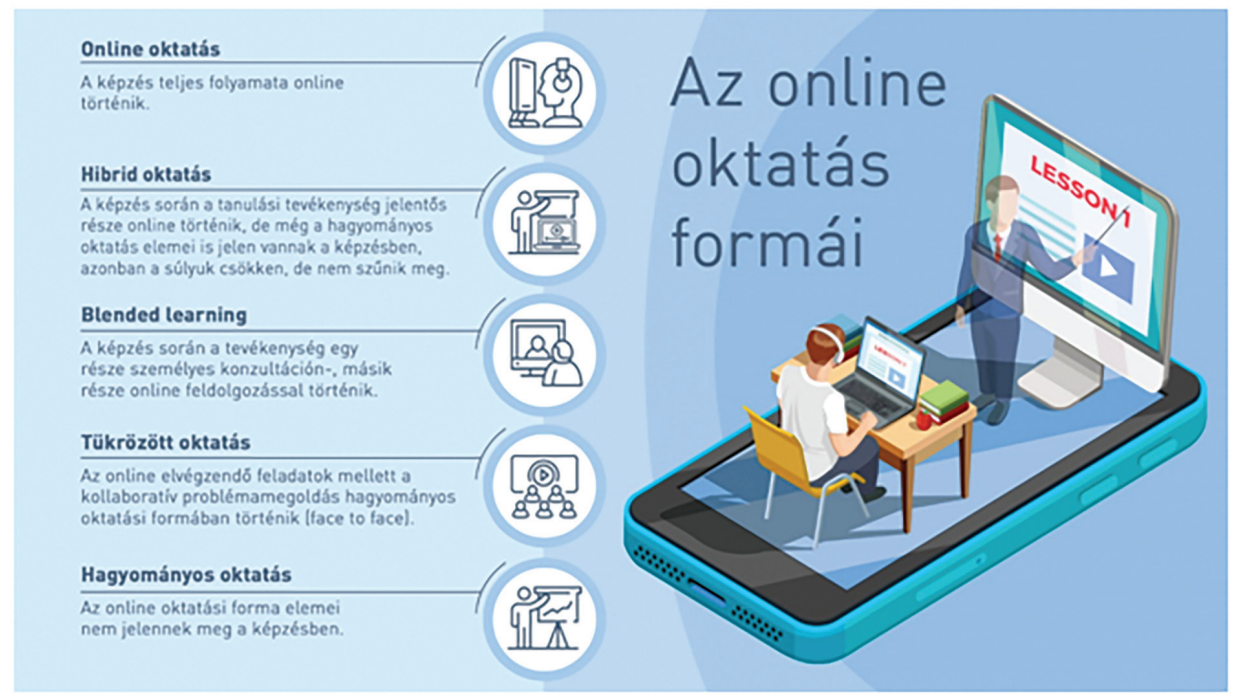

6. ábra. Az oktatási formák változatai ${ }^{24}$

${ }^{23}$ Hunya, Márta. 2016. "Digitális és online tanulás." In Az Európai Unió az oktatásról: stratégiai irányok és értelmezések, edited by Széll Krisztián, 33-40. Budapest: Oktatáskutató és Fejlesztő Intézet

${ }^{24}$ The rise and rise of Digital Education. http://visual.ly/rise-and-rise-digital-education (2019.11.20. ) /ford: a szerzö/ 
1. Hagyományos oktatás: amikor nem használjuk az online oktatási forma elemeit.

2. Tükrözött oktatás: hagyományos oktatási keretben zajlik az óra, de az oktató szerepe átalakul: kihasználva az IKT-eszközök kínálta lehetőségeket a tanulók egyéni tempóban dolgozzák fel a tananyagot, részben a tanórán, részben előzetesen otthon. A módszer támogatja a kollaboratív problémamegoldást, és egyéni haladási utat kínál a tanulóknak.

3. Blended learning: a kurzus egy része személyes konzultációkon, de a tananyagok feldolgozása online, önállóan történik. A tanár elindítja a tanulási folyamatot, majd online mentorként támogatja a tanulást vagy az önálló online tananyag-feldolgozás közben, vagy annak végeztével egy vagy több személyes konzultációval támogatja a tanulási folyamatot.

4. Hibrid oktatás: az oktatás online történik, de még a hagyományos osztálytermi oktatás elemei is jelen vannak a képzésben, súlyuk csökken ugyan, de nem szünik meg.

5. Online oktatás: az oktatás teljes folyamata online történik.

Az online oktatás elterjedését a nyílt rendszerek megjelenése és egyre szélesebb körü alkalmazása tette lehetővé. A nyílt oktatási rendszerek három konstrukcióban jelenhetnek meg: az OER, az OCW és az MOOC-kurzusok formájában.

OER: nyílt oktatási erőforrások (Open_educational_resources), melyek lényege, hogy minden teljesen szabadon felhasználható. Az OER azon az elképzelésen alapul, hogy a tudást terjeszteni kell, és az internet lehetőségeit kihasználva szabadon megosztani a társadalom egésze számára. A két legfontosabb szempontja:

- a nyitottság, mely alatt a szabadon rendelkezésre bocsátást értjük, és

- a korlátozások minimalizálása, annyira, amennyire a körülményekből (müszaki, jogi vagy a vételár) adódó akadályok engedik.

Az OER magas szintű oktatási anyagokhoz biztosít szabad hozzáférést, és magába foglalja:

- „Ateljes tananyagot(előadásanyagokat, tankönyvet, videoállományokat, multimédiás alkalmazásokat, tantervet),

- minden oktatási szinten (de elsősorban az élethosszig tartó tanulás színterén),

- szabad hozzáférésủ nyílt adattárak létrehozásával,

- melyben az oktatási anyagokat tanárok készítik,

- azzal a céllal, hogy tanároknak és diákoknak biztosítsák, hogy részt vegyenek a tanítási/tanulási folyamatokban." ${ }^{25}$

${ }^{25}$ EPRSLibrary: Open Education: OER, OCW And MOOCs. 2014. https://epthinktank. eu/2013/10/01/open-education-oer-ocw-and-moocs (2019. november 20.) 
Azonban az OER csak az anyagokhoz való hozzáférésre vonatkozik, a felhasználásra nem: az OER által közzétett anyagokat hagyományos környezetben is használhatják, így ez nem feltétlenül jelent e-learninges oktatási folyamatot. Ezzel szemben az OCW (Open Course Ware) és a MOOC (Massive Open Online Courses) igen.

Open Course Ware (Nyílt megosztású kurzusok (tan)anyagai) „lényege kristálytiszta: ingyenes, elérhető és újrahasznosítható." ${ }^{26}$ Jól tükrözi az OER-től való különbségét, ha megnézzük egy másik meghatározását az OCW-nek: „Egyetemi szintü oktatási anyagok szabad és nyílt elektronikus kiadványa". ${ }^{27} \mathrm{Az}$ OCW-t alapvetően felsőoktatási intézmények fejlesztik, gyakran tanfolyamokat szerveznek az anyagokhoz kapcsolódóan, melyek tartalmaznak értékelési szempontokat, tematikus tervet. Az OCW során igyekeznek mindent a CC-BY (Attribution (CC-BY) Nevezd meg!) Creative Commons License jogoknak megfelelöen biztosítani, ami alapvetően a szabad licencủ hozzáférést jelenti. De intézménytől függően müködhet szigorúbb megkötéssel is, és egészen a CC BY-NC-SA (Attribution Non-Commercial Share Alike (Nevezd meg!-Ne add el!-Így add tovább!) gyakorlatáig terjedhet. Az OWC-rendszereknél fontos, hogy bármilyen OCW-oldalra lépünk, rögtön tájékoztatnak arról, hogy milyen felhasználásra számíthatunk a CC-jogok pontos feltüntetésével.

Az OCW-vel szemben a MOOCs ingyenes, elérhető, de nem valószínü, hogy újrahasználható. A MOOCs (Tömeges nyílt online kurzusok) ingyenes online tanfolyamok formális belépési követelmények nélkül, korlátlan számú felhasználó számára. A folyamatnak része lehet az interakció, a visszacsatolás és az értékelés (rendszerint automatizált formában), de nem vezetnek hivatalos nyilvántartásokat. Meg kell azonban különböztetni a MOOC formáit:28

- xMOOC: (eXtended Massive Open Online Course) a hagyományos oktatási tevékenységekhez leginkább hasonló, de online környezetben megvalósuló oktatás, aminek a központjában az oktató áll.

- cMOOC (Connectivsm MOOC): konnektivista MOOC, a tanulók saját maguknak állítják össze a tematikát, tervezik meg a tananyagot. Egy egyetemi szemináriumhoz hasonló.

- DOCC (Distributed Online Collaborative Courses): nyitott és megosztott online kollaboratív kurzusok, amelyekben a kurzus tananyaga megosztott a tanulók és az intézmények között, de a tényleges admi-

${ }^{26}$ Uo.

${ }^{27}$ Uo.

${ }^{28}$ Forgó Sándor - Racsko Réka: A pedagógiai rendszertervezés és újmédia alapú MOOC-kurzus jellemzői a felsőoktatásban. = ICEM 2014, 64th Conference and General Assembly of the International Council for Educational Media. Eger, Eszterházy Károly Egyetem. 2014. http://www.icem.education/conferences/icem-2014-agria-media/ download/?showMeta=2\&ext $=$.pdf (2019. november 20.) 
nisztráció az intézmények között változhat. A hallgatók dolgozhatnak egymással az intézményeken keresztül online elemek segítségével.

- BOOC (Blended-MOOC): a MOOC-nak ez a típusa a hagyományos egyetemi oktatást és az online oktatási formát együttesen végzi.

- SMOC (Synchronous MOOC): az előadások élőben zajlanak, amire a hallgatóknak be kell jelentkezniük, és végig kell hallgatniuk.

- SPOC (Small Private Online Courses): a csoportban résztvevők száma korlátozott. A tanár-diák interakció sokkal zártabb a hagyományos osztálytermi interakciónál.

Míg a cMOOC-ra jellemző, hogy a résztvevők maguk határozzák meg a tanulás ütemét, addig az xMOOC-ot az OCW-hez hasonlóan kiegészítik egy didaktikai modellel.

A MOOC-kurzusok esetén a szabad felhasználású forma a ritkább megvalósulás. Rendszerint a MOOC-kurzusok oldalain elérhető tartalmak teljes egészében (a benne lévő képek, hang és videoállományok, elrendezések, illusztrációk stb.) a kurzust üzemeltető vállalat tulajdonát képezik és copyright védi őket. Míg az OCW-rendszer felhasználói a tananyagokat akár többször használják, fejlesztik, majd terjesztik a továbbfejlesztett változatot, addig a legsikeresebb MOOC-k licenc alatt állnak, a felhasználói „csak nézők”. De ez, kreditekkel, továbbhaladást segítő elemekkel is kiegészítve, be tudja tölteni az alapvető célját: hogy széles körnek biztosítsa a tanulási lehetőséget.

Az Online Learning Consortium (OLC) 2016-os felmérése szerint az amerikai tanulók negyede legalább egy online kurzust elvégzett már. ${ }^{29}$ A 2018 év végi kutatások már arról számolnak be, hogy 2011-ben átlépte a 100 milliót a legalább egy online kurzust elvégzők száma, 2017-ben pedig évi 23 millióval nőtt ez a szám, majd 2018-ban kicsit lassulva 20 milliós a növekedés - a MOOC-kurzusokat kínáló szolgáltatók (pl. Coursera) azonban rekord bevételt értek el 2018-ban. ${ }^{30}$

A MOOC-kurzusok magas számához a világ számos könyvtára is hozzájárul. Ennek eltérő megvalósulási formáit láthatjuk:

- egyetemi könyvtárak járnak elől a folyamatban, és az egyetemük e-learning felületén kínálnak MOOC-kurzusokat;

${ }^{29}$ Online Learning Consortium: Addressing the higher education act for the 21 st century learner. 2016. https://olc-wordpress-assets.s3.amazonaws.com/uploads/2017/02/OLC-Higher-Education-Online-Learning-Statistics.pdf (2019. november 20.)

${ }^{30}$ Shah, Dhawal: By The Numbers: MOOCs in 2018. ClassCentral MOOCreport. Accessed 2018.12.11. https://www.classcentral.com/report/mooc-stats-2018 (2019. november 20.) 
- más egyetemekkel összekapcsolódva történik az e-learning oktatás (pl. a British Library a Nottingham-i Egyetemmel [University of Nottingham] közösen indít online kurzusokat); ${ }^{31}$

- saját képzésmendzsment rendszeren keresztül kínálják a képzést. Például az ALA (American Library Association) saját rendszerében kínál webináriumokat (többek között a MOOC-kurzus és a közkönyvtárak témakörében is) és tanúsítvánnyal záruló online kurzusokat.

Magyarországon is elindult a folyamat: a könyvtárak, múzeumok is kezdenek megjelenni az online oktatási palettán, és a tudományos tájékoztatást szolgáló webináriumoktól (pl. Miskolci Egyetemi Könyvtár ${ }^{32}$, az ELTE Egyetemi Könyvtár és Levéltár Egyetemi Könyvtár sorozatai ${ }^{33}$ ) egészen a tanúsítványt adó online képzésekig (pl. Museum Learning, Debreceni Egyetem e-learning formában tartott könyvtárismereti kurzusai) találunk kínálatot.

A 4. ipari forradalom és a hatására megváltozott tanulási szokások, fejlődő technológiai környezet, támogatást váró társadalom együttesen komoly kihívásokat, ugyanakkor lehetőségeket is jelentenek a könyvtárak számára. A könyvtáraknak meg kell találniuk azt az utat, amivel aktív részesei lehetnek a jövő társadalmának!

\section{Rezümé}

A jelenleg zajló 4. ipari forradalom jelentős mértékben átalakítja a társadalom működését. Átalakul a munkaerőpiac: jelentős számú szakma tünik el és újak jelennek meg, valamint megváltoznak a munkavállalóktól elvárt képességek is. A társadalomnak szüksége van olyan intézményekre, amelyek segítik a felkészülést a kihívásokra. Az amerikai lakosság a könyvtáraktól várja a 4. ipari forradalom hatására elterjedő új technológiai eszközök használatára való felkészítést, valamint a digitáliskompetencia-szint fejlesztését. A társadalmi elváráson túl a nemzetközi stratégiák, valamint a tanulási környezetben bekövetkező változások új szerepköröket jelentenek a könyvtárak számára. Egy 21. századi könyvtárnak a hagyományos könyvtári funkciók ellátásán túl:

- digitális oktatási központként,

- tanulási környezetként, valamint

- online oktatási színtérként is funkcionálnia kell.

Tanulmányomban a nemzetközi stratégiák figyelembevételével mutatom be ezek létjogosultságát.

${ }^{31}$ The British Library: The British Library joins forces with The University of Nottingham to offer a free online course. 2015. https://www.nottingham.ac.uk/news/pressreleases/2015/february/ joining-forces-with-the-british-library-to-offer-a-free-online-course.aspx (2019. november 20.)

${ }^{32}$ Miskolci Egyetemi Könyvtár Jövő könyvtára webinárium sorozat. http://www.lib.unimiskolc.hu/web/konyvtar/jovo-konyvtara

${ }^{33}$ ELTE Egyetemi Könyvtár és Levéltár Egyetemi Könyvtár webináriumai https://konyvtar. elte.hu/hirek?field_kulcsszavak_tid=webinárium 


\section{The library-related aspects of digital transformation in the light of international trends}

The current Fourth Industrial Revolution radically changes society in the 21 st century. Several professions and trades disappear and new ones emerge on the labour market while the skills required of employees have changed as well. Hence the need for institutions capable of preparing people to face such challenges becomes pressing. In the United States libraries are expected to train the population for the use of technological devices introduced during the Fourth Industrial Revolution along with improving their respective digital competence levels. Furthermore, various international strategies and the changing learning environment bring about new tasks for libraries. Thus in the 21 st century, in addition to their traditional functions, libraries have to become

- digital education centres

- learning environments

- $\quad$ on-line educational spaces.

My essay explores the reasons for and the results brought about by these changing expectations, taking the relevant international strategies into consideration.

LENGYELNÉ MOLNÁR TÜNDE tanszékvezető Eszterházy Károly Egyetem Médiainformatika Tanszék 